\title{
Behandling av selvskade \\ - hva virker, og hva virker ikke?
}

\author{
Av Line Indrevoll Stänicke
}

\section{SAMMENDRAG}

Selvskading øker i en rekke land og spesielt blant unge jenter. Formålet med denne artikkelen er å presentere bred kunnskap om behandling av selvskade. Resultater fra randomiserte kontrollstudier og effektstudier, kunnskap fra psykoterapiforskning, samt funn fra kvalitative studier gjengis for å diskutere om noen behandlingsmodeller eller intervensjoner er bedre enn andre. Det fremheves at noen behandlingsmodeller viser effekt, men at det er uklart hvordan spesifikke og felles behandlingsfaktorer, samt felles elementer på tvers av behandlingsmodellene, har innvirkning på behandlingsutfall. Forfatteren argumenterer for betydningen av å utforske hvilken funksjon selvskadingen har i den enkeltes hverdag. Behandlingsmodellene fremhever i ulik grad selvskade som affektreguleringsstrategi og fokuserer på alternative mestringsstrategier, som forsøk på representasjon og kommunikasjon og fokuserer på å finne nye uttrykk for opplevelser, eller som eksistensiell og relasjonell utforskning og fokuserer på tillit i terapirelasjonen. Et heterogent perspektiv på forskningsmetoder, behandlingsmodeller og selvskadingens funksjon er viktig for å forstå et komplekst fenomen som selvskade. Heterogenitet i tiltak og intervensjonsfokus bør vektes i enhver behandlingssammenheng fordi pasientene er forskjellige. Kunnskap om selvskade bør også relateres til utviklingspsykologiske utfordringer i ungdomstiden og sosiokulturelle faktorer for å forstå økningen i selvskade blant ungdom generelt og unge jenter spesielt.

\section{ABSTRACT}

Self-harm is increasing in several countries and especially among young girls. The aim of this article is to present broad knowledge on treatment of self-harm. Results from randomized control studies and effect studies, knowledge from psychotherapy research, and findings from qualitative studies are presented to discuss if some treatment models or interventions are better than others. It is underlined that some treatment models show effect but, still, unclear how specific and common treatment factors, and common elements across treatment models, have an effect on treatment outcome. The importance of exploring the function of self-harm in the patient's everyday life is underlined. Treatment models may in different degree highlight self-harm as affect regulation and focus on alternative coping strategies, or a way to represent and communicate and focus on finding ways to express experiences, or as existential and relational exploration and focus on trust in the therapeutic relationship. A heterogenic perspective on research methods, treatment models and the function of self-harm is of importance to understand a complex phenomenon as self-harm. A diversity in interventions and focus of treatment should be weighted in every treatment process because patients are different. Findings on self-harm should be related to developmental challenges during adolescence and sociocultural factors to understand the increase of self-harm among youths in general, and young girls specifically. 

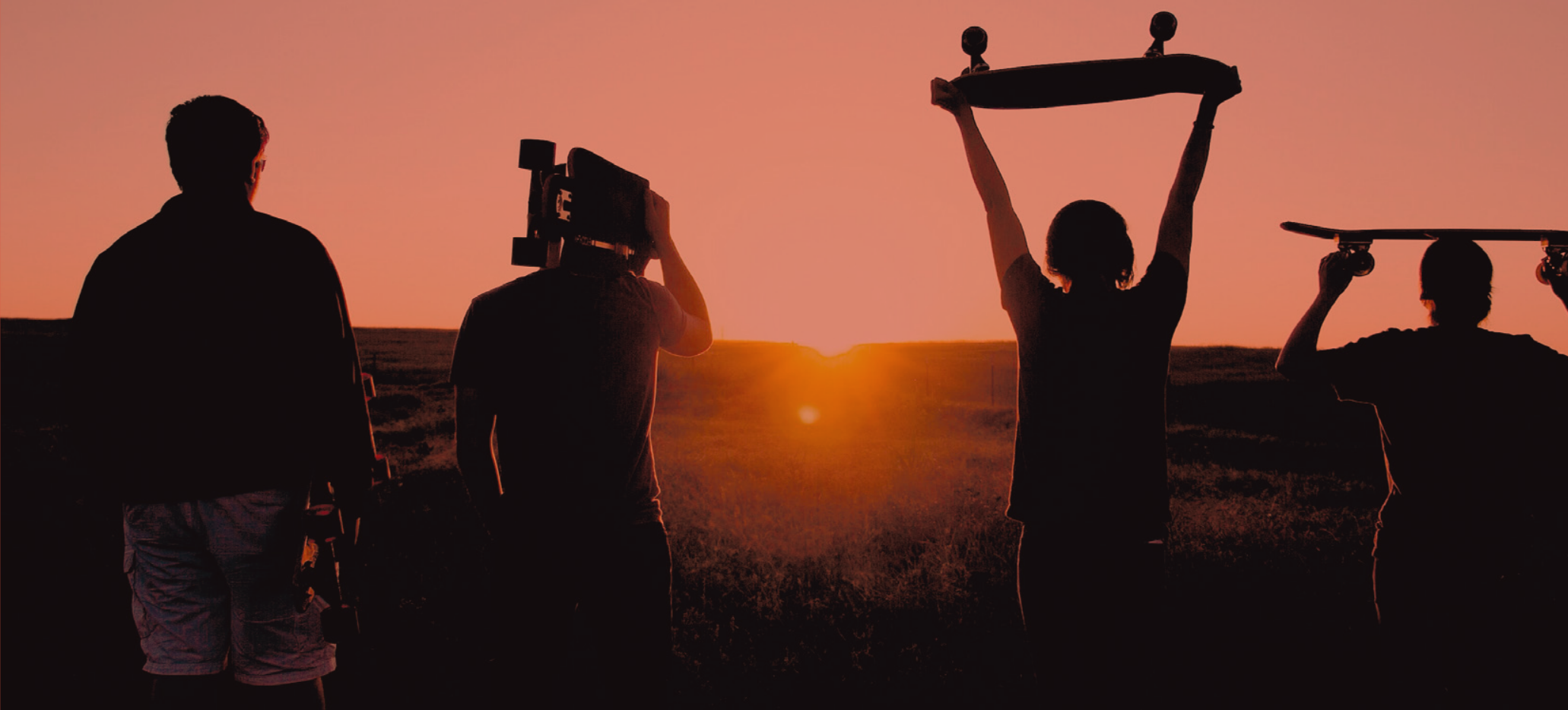

\section{Innledning}

«Vi snakket om det ... vi planla alt ... hvordan jeg skulle slutte ... men det interesserte meg ikke i det hele tatt ... det var enormt kjedelig ... jeg tror jeg kunne klart å slutte, men jeg kan ikke slutte med all selvdestruktivitet. Hvis jeg slutter å skade meg så røyker jeg mer. Hvis jeg slutter å røyke så kutter jeg mer. Hvis jeg spiser normalt så både røyker og kutter jeg mer. Jeg kunne sluttet med én av tingene, men ikke alle (...). Men etter hvert ble jeg opptatt av å få det bedre.» (Marit, 16 år)

Selvskade kommer oftest til uttrykk som kutting, brenning eller slag mot egen kropp, med milde, moderate eller alvorlige konsekvenser. Det er en pågående definisjonsdiskusjon om selvskading kan inneholde en intensjon om å ville dø av handlingen (Hawton et al., 2015; Nock, 2014; Miller et al., 2019). Uavhengig av definision viser en rekke studier at selvskading ofte starter i 12-årsalderen, og internasjonale studier viser at opp mot $17 \%$ av ungdommer i normal populasjon bekrefter å skade seg (Swannell et al., 2014). En fersk studie viser overensstemmende tall i Norge - 16,2 \% (Tørmoen et al., 2020). Jenter skader seg 5 ganger så mye som gutter, men gutter bekrefter mer indirekte former for selvskade (risikoatferd som rus, slåssing og bilkjøring) (Miller et al., 2019). Det er imidlertid stor variasjon - noen skader seg et par ganger, noen i en periode, og andre langt inn i voksen alder.

Selvskade er også assosiert med selvmordsfare og sees ved en rekke psykiske lidelser som depresjon, spiseforstyrrelse, rusmisbruk og personlighetsforstyrrelse (Miller et al., 2019). Selvskade er foreløpig ikke en diagnose, men assosiert med flere risikofaktorer som overgrep, mobbing, lav selvtillit og problemløsningsvansker (Larkin et al., 2014). Mange som skader seg ønsker hjelp, men mange vegrer seg mot å søke behandling, synes det er vanskelig å motivere seg for å slutte å skade seg, eller beskriver ubehagelige opplevelser i møte med helsepersonell (Brown \& Kimball, 2013; Lindgren et al., 2004; MacDonald et al., 2020). Terapeuter kan erfare håpløshet og engstelse i møte med pasienter som selvskader, og spesielt hvis de fortsetter å skade seg på tross av omfattende behandlingstiltak over tid (Rayner et al., 2018; Saunders et al., 2012). Hvordan kan de best få hielp?

Tema for denne artikkelen er behandling av selvskade. Formålet er å fremheve bred kunnskap om virksom behandling. Systematiske oversikter av evidensbaserte behandlingsstudier, studier på evidensbasert praksis, kvalitative studier om pasienter og terapeuters opplevelse av behandling, samt kunnskap om psykoterapiforskning fremheves for å drøfte følgende spørsmål: 
1) Finnes det evidensbaserte behandlingsmodeller som er bedre enn andre? 2) Hva vil det si at en behandling ikke virker eller har liten effekt? 3) Hvilke faktorer kan hielpe oss å forstå behandlingsforskningen?

Noen systematiske oppsummeringer av evidensbaserte behandlingsstudier for å redusere selvskade er publisert (Hawton et al., 2015; 2016; Morken et al., 2019; Ougrin et al., 2015; Saunders \& Smith, 2016; Turner et al., 2014; Witt et al., 2017). I det følgende vil presentasjonen av behandlingsstudiene ikke være basert på et systematisk litteratursøk, men artikkelen fremhever noen behandlingsmodeller som er understreket som evidensbaserte i flere oversiktsstudier. Presentasjonen viser tendenser i kunnskapsfeltet, og fremhever noen dilemmaer og kunnskapshull som kan være viktige å øke kunnskap om i en videre utvikling av behandlingsmodeller rettet mot selvskade. Ved å presentere behandlingsforskningen i bred forstand understrekes betydningen av heterogenitet i valg av data, forskningsmetoder og forståelsesperspektiv ved et komplekst fenomen. Ulike data og forskningsmetoder kan fremheve ulike aspekter ved selvskading. Kanskje finnes det ikke ett svar på hvilken behandling som virker best?

Artikkelen fremhever forskning på behandling av direkte repeterende selvskade med og uten selvmordsintensjon, og utelater studier som primært fokuserer på selvmord. Det fokuseres ikke på indirekte selvskade eller kulturelt akseptert og smertefull kroppsmodifikasjon, som tatovering, scarification eller piercing (Favazza, 1987).

\section{Systematiske oversiktsstudier og evidensbasert behandling - hva virker?}

Systematiske oversiktsstudier har giennomgått behandlingsmodeller og terapeutiske intervensioner for å redusere selvskade og vurdert om behandlingen er evidensbasert (Hawton et al., 2015; 2016; Morken et al., 2019; Ougrin et al., 2015; Saunders \& Smith, 2016; Turner et al., 2014; Witt et al., 2017). Betegnelsen «evidensbasert behandling» viser til bestemte krav for å undersøke om en behandling har effekt, såkalt evidens, som er bedre enn placebo eller ikke-evidensbasert behandling (ofte kalt Treatment as usual eller TAU) eller like god som en etablert behandling (Rønnestad, 2008). Ved bruk av randomiserte kontrollstudier (RCT), sammenliknes en eksperimentgruppe med en kontrollgruppe, der variablene skal være så like som mulig (som type pasienter mht. alder og diagnostikk) med unntak av den eksperimentelle betingelsen - som det å få en bestemt behandling. RCT-studier krever stor grad av kontroll og påfører behandlingssituasionen mange restriksjoner. Fordelen er at en kan anta at den effekten behandlingen synes å ha på endringen er kausal, det vil si å ha høy indre validitet. Av denne grunn ekskluderes pasientgruppen ofte fra behandlingsstudier, med unntak av studier på borderline personlighetsforstyrrelse (BPD) (American Psychiatric
Association, 2013). Behandling for BPD har i flere år vært antatt å ha liten effekt, men flere oversikter over randomiserte kontrollstudier av strukturerte behandlinger for denne pasientgruppen viser effekt også på å redusere selvskade (Cristea et al., 2017; Kongerslev et al., 2015; Storebø et al., 2020).

I flere systematiske oversikter fremheves at behandlingsmodellene kognitiv terapi, dialektisk atferdsterapi og mentaliseringsbasert terapi hver for seg viser signifikant effekt på reduksjon av selvskade, depresionssymptomer og selvmordstanker (Cristea et al., 2017; Hawton et al., 2015; 2016; Kongerslev et al., 2015; Morken et al., 2019; Ougrin et al., 2015; Saunders \& Smith, 2016; Storebø et al., 2020; Turner et al., 2014). Behandlingsmodellene har noe ulikt behandlingsfokus selv om det også er mange overlappende elementer som vil drøftes senere. I kognitiv atferdsterapi (KBT) antas negative tanker og forventninger, dårlig stresstoleranse og passive problemløsningsstrategier å skape sosial isolasjon, håpløshetsfølelse og motivere for selvskading - betegnet som «cry of pain» (Williams, 2014). Kognitiv restrukturering, eksponering og nyansering av mestringsstrategier antas å redusere håpløshet og øke stresstoleranse. Det er foretatt 18 RCT-studier av KBT på voksne og ungdommer, og i tillegg til de generelle funnene nevnt tidligere viser deltagerne spesielt bedret problemløsningsevne (Hawton et al., 2015; 2016). I dialektisk atferdsterapi (DBT) integreres kognitiv atferdsterapi med en dialektisk holdning eller innstilling - det å akseptere og balansere oppfatninger og å motivere for forandring (Linehan, 1993). Spesielt analyseres selvskade ut ifra betingelser (tanker, følelser og hendelser) før, under og etter en episode. Terapihemmende atferd arbeides eksplisitt med for å oke samarbeidsrelasjonen, for at pasienten skal få mest ut av behandlingen, og for å øke ferdigheter som affektregulering, stresshåndtering og problemløsning. Behandlingsmodellen har en tydelig struktur og består av ukentlig individualterapi, ferdighetsgruppe, mulighet for telefonveiledning, og ukentlig teamveiledning for terapeuten. Det er foretatt 18 RCT-studier på DBT for voksne og ungdommer (Mehlum et al., 2019). I tillegg til redusert selvskading viser pasienter som fikk DBT mindre håpløshet og færre borderlinesymptomer, og fortsatt redusert selvskading ved oppfølging 1 og 3 år etter behandlingsslutt (Mehlum et al., 2019). I mentaliseringsbasert terapi (MBT) understrekes utforskning av relasjonelt vanskelige situasjoner i individualterapi kombinert med gruppeterapi (eller familieterapi) for å stabilisere selvfølelse, øke affektregulering og mentalisering. Mentalisering viser til det å forstå egne og andres handlinger i lys av følelser, tanker og fantasier. Selvskadende atferd menes å kunne uttrykke opplevelser av seg selv og andre som ikke er representert og som kan bli integrert i en terapeutisk prosess. Det er giennomfort 3 RCT-studier på MBT for voksne og ungdommer (Bateman \& Fonagy, 2008). Pasienter som har giennomgått $\mathrm{MBT}$ viser redusert 
selvskade, samt $₫ k t$ mentaliseringsevne og redusert sosial unngåelse i kriser (Rossouw \& Fonagy, 2012).

Konklusionen så langt er at det finnes strukturerte behandlingsmodeller som viser evidens for å redusere selvskade blant voksne og ungdommer. Modellene kan forstås som bedre enn andre behandlinger eller intervensionsprogrammer. Behandlingene er multimodale og omfatter individuell psykoterapi i kombinasion med andre behandlingstiltak - det være seg foreldreveiledning, familieterapi, ferdighetstrening i gruppe og/eller psykoedukasion. Jeg vil senere komme tilbake til hvordan vi kan forstå at behandlingsmodeller med noe ulikt behandlingsfokus kan vise relativt lik effekt (Cristea et al., 2017), samt det at ingen av behandlingsmodellene hjelper alle (Kongerslev et al., 2015). La oss først se nærmere på hvilke behandlingstiltak som ikke har vist effekt, og hva det vil si at effekt ikke er påvist.

\section{Hva virker ikke?}

Med unntak av overnevnte terapiformer konkluderer flere oversiktsartikler med at det er få entydige positive resultater for en rekke intervensionsprogrammer for voksne som skader seg - som interpersonlig problemløsning, atferdsterapi, hjemmebasert problemløsning, langtidspsykoterapi, eller intensivt døgn- eller kommunetilbud (vs. TAU) (Hawton et al., 2016; Saunders \& Smith, 2016; Turner et al., 2014; Storebø et al., 2020). Få intervensionsprogrammer har også tydelig effekt for ungdom som skader seg (Hawton et al., 2015; Morken et al., 2019; Ougrin et al., 2015). Selv om en RCT på gruppebasert terapi for ungdom viste effekt på å redusere selvskade, mindre bruk av helsetjenester og mindre atferdsforstyrrelse, ble ikke resultatene funnet igien i nye studier (Hazell et al., 2009). I en MBTgruppeterapistudie over ett år med ungdommer viste deltagerne færre BPD-symptomer, mindre depresjon, selvskade og generell patologi, og funnene var assosiert med økt tillitt til venner og foreldre samt økt mentalisering (Bo et al., 2017). Samtidig viste en påfølgende RCT med MBT-gruppeterapi for ungdom kombinert med foreldregruppe ingen effektforskjell og større frafall i MBT-gruppen (Beck et al., 2016). Det er heller ikke funnet klar evidens for hiemmebasert familieintervension (Ougrin \& Asarnow, 2018).

Hele 14 studier viser liten effekt av digitale intervensioner (som mobil- eller internettbasert terapi) på selvskade, men effekten er bedre enn å stå på venteliste og kan redusere selvmordstanker (Hawton et al., 2015; 2016; Witt et al., 2017). Når det gielder utprøvinger av psykofarmaka, finnes det ikke medisiner som er spesifikt mot selvskadende atferd - forståelig nok - og heller ikke mot BPD, men som kan rettes mot komorbide plager som svingende stemningsleie, angst, impulsivitet eller grensepsykotiske symptomer ved indikasjon - type antidepressiva med SSRI eller lavdoseantipsykotika (Hawton et al., 2015; 2016; Miller et al., 2019; Ougrin et al., 2015). Mest uheldig er bruk av benzodiazepiner mot angst eller søvnvansker som kan gi et avhengighetsproblem. Selv om noen medikasjonsutprøvinger viser lovende resultater, er det behov for replikasjon.

Alvorlig selvskade er som nevnt assosiert med det å ha selvmordstanker, -planer og ha giort forsøk, noe som innebærer at risikovurdering og økte sikringstiltak som dogninnleggelse kan være nødvendig og viktig. Pasienter som fikk DBT i døgnavdeling var i behov av mindre observasion, viste mindre selvskade og selvmordsforsøk, samt færre dager innlagt sammenliknet med TAU (Tebbett-Mock et al., 2019). Som nevnt er MBT utført i døgn med positiv effekt for voksne pasienter, og det er også behandlingsstudier - om enn ikke RCT - på ungdommer i døgnenhet med MBT som viser effekt (Laurenssen et al., 2014). Basal eksponeringsterapi (BET) er også utprøvd på pasienter med alvorlige og sammensatte psykiske lidelser med alvorlig selvskade, og som kan tyde på en reduksjon i innleggelsesfrekvens (Hammer et al., 2017).

I retningslinjene for Forebygging av selvmord i psykisk helsevern (Sosial- og helsedirektoratet, 2008) anbefales kun korte innleggelser i samarbeid med poliklinikken for pasienter med tilbakevendende selvmordsproblematikk og alvorlig selvskading (samme ved NICE guidelines). En nasjonal kartlegging antyder et sammenfall mellom lengde på innleggelsen, omfang på selvskaden og samarbeidsproblemer i form av diskusion om diagnose, tiltak og ressursbruk (Holth et al., 2018). Det kan være bekymringer om mulighet for symptomforverring som psykosenær dekompensering, men også negativt samspill med andre pasienter eller mulig «smitte» av selvskadende atferd. Tiltak som døgninnleggelse, isolering og fastholding kan også hindre plass til endringsfokus for å øke pasientens autonomi, håp og selvfølelse (Stangeland, 2016; Larsen, 2011). Kommunikasjonen mellom behandler, hjelpepersonell og pasienten kan bli svært vanskelig med mistillit og eskalering av risikoatferd heller enn reduksjon av selvskade. Dette betyr ikke at all døgnbehandling er uten effekt eller har kun negativ effekt. Det kan si noe om kompleksiteten ved pasientens vansker. Hva som er riktig behandlingstiltak må vurderes fra pasient til pasient og den aktuelle situasion.

Oversiktslitteraturen gir ikke et entydig svar på hvilke behandlingsmodaliteter som er mest virkningsfulle - om polikliniske tiltak er bedre enn døgn, kort tid bedre enn lang tid, eller individualterapi fremfor gruppe-, foreldre- eller familieterapi. Samtidig viser studier at flere strukturerte multimodale behandlingsmodeller viser effekt. Kanskje kan det si at flere parallelle intervensjoner i ulike modaliteter kan være virksomt? Behandlingstiltakene bør således omhandle både personen selv og familien/nettverk. Familieintervensjoner, og kanskje også gruppeterapi, bør kombineres med individuelle samtaler. La oss se litt nærmere på noen utfordringer ved effektstudier etter RCTstandard. 


\section{Behandlingsstudier og evidensbasert praksis}

Kriterier for evidensbasert behandling beskrevet med RCT-design, er drøftet som for snevre og mer passende i medisinsk enn psykologisk behandling (Carey \& Stiles, 2015; Nissen-Lie, 2018). Utfordringen er å få kontroll på alle variable som kan påvirke endringsprosessen i behandlingen. En innvending er at pasienter er veldig forskjellige når det gielder motivasjon, åpenhet, kognitive evner, ressurser og støtte (Anderson et al., 2015). En annen innvending er at pasienter ikke er passive mottagere av en behandling hvor en testbetingelse har effekt eller ikke - endring er en aktiv prosess (Carey \& Stiles, 2015). Randomisering og standardisering av intervensioner kan også utfordre terapeutens integritet, relasjonelle åpenhet og mulighet for å tilpasse behandlingen. Ytre validitet, overførings- og generaliseringsverdi til virkelighetens praksis kan bli lavere på grunn av alle restriksjonene ved RCT, noe som gir naturalistiske studier en fordel (Nissen-Lie, 2018). Det at en modell ikke er forsket på eller utprøvd i en RCT-studie betyr heller ikke at den ikke virker. Vi kan kanskje til og med si at selv om en behandlingsmodell ikke har vist effekt i én studie så vet vi ikke med sikkerhet om behandlingen ikke virker.

Begrepet «evidensbasert praksis» er en mer overordnet betegnelse, og viser til det å bruke best tilgiengelig forskning med klinisk ekspertise der vi tar hensyn til pasientens egenskaper, kultur og preferanser (Ronnestad, 2008). Det kan nevnes at flere forebyggings- og intervensionsprogrammer som rettes mot personer som skader seg er under utprøving, men enda ikke med RCT-studie. Et eksempel er «Stepped care modellen» der 4 sesioner med kartlegging, krisehåndtering og problemlosningshielp tilbys innen kommunal helsetjeneste til personer etter legevaktbesøk grunnet selvskade og selvmordsproblematikk og for eventuell lengre behandling (Huxley et al., 2019). Studien har lovende resultater med effekt på selvmordsrisiko, alvorlighet av borderlinesymptomer og livskvalitet. Et annet eksempel er «Signs of self-injury prevention program», som inneholder en edukativ manual og en dvd for elever og lærere, og som synes å øke kunnskap og hielpesøkende holdning (Muehlenkamp et al., 2009). I dag diskuteres også trinnvise forebyggings- og intervensionstiltak, som «Clinical staging model», der omfang av selvskading eller antall kriterier på BPD får følger for grad av informasion, edukasion eller digitalt helsetilbud med kort- eller langvarig psykoterapi (Hutsebaut et al., 2020).

Begrepene evidensbasert behandling og evidensbasert praksis fremhever en generell utfordring ved behandlingsstudier om at effekt giengis med giennomsnitt, noe som overskygger det at noen har mye, moderat eller liten effekt av en behandlingsmodell. Ingen behandlingsmodell hielper alle pasienter. I tillegg rapporterer om lag $5 \%$ varige negative effekter av psykoterapeutisk behandling (Crawford et al., 2016).
Vi kan kanskie anta samme eller høyere resultat i behandling med pasienter som skader seg gitt deres interpersonlige utfordringer. Andelen «drop out» på RCT-studier er også relativt høy, og varierer mellom 20-54 \% (Kongerslev et al., 2015). Selektive inntakskriterier i en RCT-studie kan også bidra til at flere med ambivalens, lav motivasion og lite ressurser takker nei til eller faller ut av en studie. Vi kan derfor stille spørsmål ved i hvilken grad behandlingsmodellene og intervensionsstudiene som har evidens er relevante for alle pasienter i alle livsfaser?

Et viktig tilliggende spørsmål er hvem og hva som definerer om en behandling virker eller ikke virker. Utfallsmål er ofte definert med standardiserte spørreskjema på symptomreduksion - som selvskade - som kan måles og kvantifiseres. Forskningsidealer om objektivitet, representasjon, etterprøvbarhet og generaliserbarhet kan redusere menneskets kompleksitet. Mennesker er ikke så lette å predikere, de har uerkjente motiver, vilje og bevissthet. De er påvirket av regler, verdier og meninger (Dilthey referert i Willig, 2013). Symptomreduksion kan bety bedring i funksion og opplevelse av å ha det bedre, men ikke nødvendigvis. En ung jente sa:

«Da jeg sluttet å skade meg ble selvmordstankene enda tydeligere».

En annen ung jente sa:

«leg er livredd for å slutte å skade meg for da ville alle tro at jeg har det bra. Jeg vil heller dø enn å slutte å skade meg».

Vi har også hørt historier fra behandlingsprosesser hvor pasientens spisevansker økte da selvskadingen reduserte, eller at selvskadingen eskalerte på tross av okte tiltak, flere timer per uke, stadig krisehåndtering, innsetting av flere medarbeidere osv. Er det fordi behandlingen ikke virket? Behandlingen virket ikke for å redusere selvskadingen der og da, men kanskie kom noe annet til uttrykk. Kanskje kunne pasientens opplevelse av at ingenting hialp komme til uttrykk og deles? Eller det at ingen så hva selvskadingen handlet om i vedkommendes livssituasion - som pågående seksuelt misbruk eller omfattende omsorgssvikt? Kanskje er det da hensiktsmessig å fortsette å skade seg? Den pågående refleksionen om hva selvskadingen eller gientagende selvmordkriser kan uttrykke i en relasionell sammenheng er viktig for å forstå behandlingsprosessen. Samtidig utfordres en slik refleksion av potensiell forhøyet selvmordsrisiko (Hawton et al., 2015; 2016). For å kunne si om en behandling virker så kan det være nyttig å se nærmere på hvilke faktorer som kan hielpe oss i forståelsen av behandlingsforskningen.

\section{Hvordan kan vi forstå evidensforskningen?}

I en oversikt av 33 RCT-studier på ulike behandlingsmodeller for BPD, viser metodene lik moderat effekt 
(Cristea et al., 2017). Dette er overens med et generelt funn i psykoterapi - «the dodo bird verdict» (Rosenzweig, 1936) - alle behandlingene hielper så alle skal få premie. Den giennomsnittlige pasient får det bedre etter terapi enn $80 \%$ av de som ikke får behandling (Wampold \& Imel, 2015). Slik kan det også være i behandling av selvskading. En forklaring på moderat lik effekt mellom KBT, DBT og MBT kan være at de ulike spesifikke teknikkene virker i giennomsnittet like godt.

Kunnskap fra psykoterapiforskning kan imidlertid tilby flere alternative forståelser. Det kan være felles faktorer - som kvaliteten på allianse mellom terapeut og pasient - som forklarer lik effekt i utfall (Lambert, 2013). For eksempel har betydningen av det relasjonelle og emosjonelle båndet mellom pasient og terapeut, der de kan dele og utvikle en felles forståelse av destruktiv atferd som selvskade og selvmord, vist seg å være avgiørende for behandlingsprosessen (Østlie et al., 2018).

Det kan også være en delt varians mellom alle terapimodeller som påvirker til lik effekt mellom modellene. Goldfried (1980; 2018) fremhever at det å støtte pasienten i at terapi er hjelpsomt, etablere optimal allianse, fokusere på problemer, og engasjere pasienten i korrigerende erfaringer og realitetstesting er viktige elementer i all behandling. Men da skulle det kanskje være lik effekt mellom de strukturerte behandlingsmodellene og annen behandling? Interessant nok hevder Hetrick og kollegaer (2016) at det ikke er så stor effektforskjell som vi kunne forvente.

Enda en mulighet er at det er noen viktige felles elementer i de strukturerte behandlingsmodellene, noe som er fremhevet spesielt i behandling for BPD (Bateman et al., 2015; Gunderson, 2011; Weinberg et al., 2011). Felles elementer kan giøre seg gieldende i alle effektive behandlingsmodeller rettet mot selvskade. Spesielt fremheves det å ha et tydelig og strukturert behandlingsperspektiv med fokus på risikoatferd og personlighetsproblemer, at intervensionene er utforskende og endringsorientert, at behandler er empatisk og aktivt arbeider med følelsesmessige vansker og behandlingsrelasjonen, samt at terapeuten diskuterer pasientarbeid og personlige reaksjoner med veileder eller i team (Bateman et al., 2015). Den manglende effektforskjellen kan blant annet skyldes at strukturerte behandlingsmodeller hjelper terapeuten til å holde fokus og maksimere effektive intervensjoner og på denne måten hindre negative reaksioner på destruktiv atferd og relasjonelle vansker (Folmo et al., 2019).

Vi trenger også å forstå variasionen i utfallet mellom pasienter som tilbys behandling. Det er ingen av de nevnte strukturerte behandlingsmodellene som hielper alle som tilbys behandlingen (Kongerslev et al., 2015). Pasientfaktorer - som type lidelse, grad av sårbarhet, ressurser, refleksjonsevne og motivasion - kan også systematisk påvirke og moderere terapiutfall (Lambert, 2013). I tillegg kan terapeutfaktorer også innvirke på variansen i terapiutfall generelt, som i hvilken grad terapeuten er varm, empatisk, respektfull, nysgierrig, fleksibel og evner å håndtere egne vanskelige følelser («fasiliterende interpersonlige ferdigheter») (Anderson et al., 2015). Terapiresultat kan variere i stor grad mellom terapeuter (Lambert, 2013).

Roth \& Fonagy (2005) stilte spørsmålet «what works for whom» og fremhevet betydningen av at terapeuter kan ha varierende fleksibilitet og responsivitet overfor ulike pasienter. Spesifikke teknikker og behandlingsmodellers effekt bør undersøkes mer systematisk i kombinasion med fellesfaktorer, terapeutfaktorer og pasientfaktorer. Interessant i denne sammenheng er en studie som viser at terapeutvariasionen er størst i behandlinger der pasienten har alvorlig patologi (Saxon \& Barkham, 2012) - som ofte gielder pasienter med moderat til alvorlig selvskade. Selvskade kan vekke sterke reaksjoner hos behandler, som engstelse og sinne, men også nummenhet, bagatellisering og manglende empati (Rayner et al., 2018; Saunders et al., 2012). Terapeuter kan bli rigide og mindre responsive for å håndtere egne følelser, og intervensionene kan som en følge bli lite tilpassede.

Kunnskap fra psykoterapiforskning antyder ikke at spesifikke teknikker ikke er viktige eller at fellesfaktorer og felles elementer betyr mest. Terapi og terapeut er vanskelig å skille (Castonguay et al., 2015). Det er nødvendig med en kompleks forståelse av endringsprosesser i psykoterapi generelt så vel som på sammensatte fenomener som selvskade: «Uten spesifikke ingredienser har vi ingen behandling, men de spesifikke ingrediensene kan heller ikke administreres uavhengig av fellesfaktorene» (Nissen-Lie, 2018, s. 5). Hvordan en terapeut utøver teknikker, hvordan disse oppleves av pasienten, og hvordan de sammen kan etablere et samarbeid omkring behandlingen er vel så viktig som hvilken intervensjon terapeuten utøver. Hverken terapeut eller pasient passivt utøver eller mottar behandling.

En måte å utforske hva som oppleves nyttig, og hva som kan ha vært vanskelig i behandling, er å se på funn fra kvalitative studier med åpne spørsmål som systematisk utforsker pasienters opplevelser. Kvalitative studier kan bidra med hypotesegenerering for å forstå funn fra behandlingsforskning, og for å utforske heterogenitet $\mathrm{i}$ endringsprosesser.

\section{Kvalitative studier - en systematisk utforskning av opplevelse}

I kvalitative studier med åpne interviuer formidler voksne som har skadet seg, og som har gått i behandling, at de fikk okt selvaksept, kontroll over vanskelige følelser, bedre relasioner, økt arbeidskapasitet, i tillegg til mindre selvskade, selvmordstanker og rusmisbruk (Katsakour et al., 2012). Spesielt fremhever de betydningen av å bli forstått i sin psykiske smerte (Brown \& Kimball, 2013). Kvalitative studier av pasienters opplevelse av BET døgnbehandling understreker 
fellesskapsfølelse, likeverd, og det å måtte selv ta ansvar (Hammer et al., 2017). Pasientene opplevde akuttposten som en mulighet for tilbaketrekning og trening for å mestre uønsket og overveldende angst, og verdsatte at helsepersonell var tilgiengelig og anerkjente deres autonomi. Ungdommer fremhever at det kan være nyttig å fjerne objekter de selv er redde for å skade seg med, men at helsepersonell må be om feedback om tiltakene hjelper (Johnson et al., 2017). De understreker at foreldre og venner er nøkkelpersoner for å forstå og finne løsninger i vanskelige situasjoner (Wadman et al., 2018). De ønsker noen å snakke med og å giøre noe sammen med (Fortune et al., 2008).

Kvalitative studier kan også bidra med kunnskap om hva som giør behandling utfordrende for personer som skader seg. Flere studier viser at voksne pasienter understreker at helsepersonell ofte misforstår selvskadingen, at de kan føle seg stigmatisert og derfor holder selvskadingen hemmelig (Brown \& Kimball, 2013; MacDonald et al., 2020). Helsepersonell blir rådet til å få mer kunnskap om selvskading som tema, ikke dømme, og å akseptere at hjelpen som tilbys ikke alltid er hjelpsom. Mange opplever seg forskjellsbehandlet på legevakt og sykehus. For eksempel kan de beskrive at personalet kun er opptatte av deres fysiske skade, at de må vente lenger og får mindre informasjon, at personalet virker uempatisk, irriterte og engstelige, og kan true med å kun behandle skaden hvis de lover å ikke skade seg mer (Lindgren et al., 2004; MacDonald et al., 2020; Taylor et al., 2009). Ungdommer fremhever at de primært oppsøker venner og deretter familie før og etter de har skadet seg og er svært ambivalente til hjelp (Fortune et al., 2008). De er redde for at problemene blir større om de forteller om dem, at de burde egentlig håndtert vanskene selv, og at de blir oppfattet som oppmerksomhetssøkende (Berger et al., 2014). De er også redde for at det de sier blir sagt videre til familien, og mange vet heller ikke hvor de kan få hjelp.

En oppsummering av 74 kvalitative og kvantitative studier av helsepersonells holdninger til pasienter, konkluderer med at sykehuspersonell, spesielt menn, har svært negative holdninger til pasienter med repetert selvskade, og mer negative enn overfor andre pasienter med unntak av rusmisbrukere (Saunders et al., 2012). I en senere oppsummering av helsepersonells holdninger fremheves at de viser negativitet og lite empati til pasienter som skader seg og at det er stort behov for kunnskap og rådgivning (Rayner et al., 2018). Kvalitative studier av terapeuters opplevelse av å arbeide med ungdommer som skader seg fremhever at arbeidet ofte vekker sterk håpløshet og bekymring, men også oppleves dypt meningsfullt - det handler om liv og død (Ramvi \& Huvestad, 2019; Robstad, 2018). La oss se nærmere på funn fra en multippel kasusstudie for å se hvordan heterogenitet i endringsprosesser kan illustreres.

\section{Et eksempel på heterogenitet - ulike veier inn og ut av selvskade}

I en kvalitativ studie med en fortolkende fenomenologisk analyse (Interpretativ phenomenological analysis) (Smith, 2008) ble 19 ungdommer (12-18 år) intervjuet om deres opplevelse av egen selvskading. Selv om alle fikk poliklinisk behandling var det ingen som uttrykte at de begynte i behandling fordi de selv onsket å slutte å skade seg (Stänicke et al., 2019). For ungdommene var det ikke selvskadingen som var problemet. Analysen av interviuene viste at ungdommene startet med selvskade for å håndtere vanskelige folelser og relasionelle problemer. Noen hadde foreldre som onsket at de sluttet med selvskading, noen ønsket selv behandling for andre psykiske symptomer, men de fleste onsket hielp med de relasjonelle og følelsesmessige vanskene som de mente var grunnen til at de begynte med selvskadingen. Det var imidlertid noen mønstre i hvordan de opplevde selvskadingen. Noen beskrev at de skadet seg på grunn av sterk selvkritikk og vanskelige følelser som sinne, skam og misunnelse. «Jeg fortjener straff», sa Anna. Andre sa at de kjente bare diffust «stress», og ikke visste hvorfor de skadet eller hva det var knyttet til i deres liv. "leg vet ikke», sa Lisa. "leg vil bare ikke føle noen ting». Atter andre relaterte skadingen til å håndtere tidligere traume og en pågående vanskelig omsorgssituasjon. «Det er bare kaos. Jeg skader meg og ingen som bryr seg», fortalte Sofia.

Analysen viste at veien ut av selvskade var dominert av ambivalens mot hjelp og til å slutte å skade seg:

«I bunn og grunn trenger jeg egentlig hielp, men ... jeg er ikke mottakelig for hjelp ... Jeg føler ikke at jeg klarer å ta imot den hielpen jeg får, fordi jeg er så opptatt av å være selvstendig og skal klare ting selv, og på en måte jeg er veldig innstilt på at den eneste som kan endre noe er meg selv. Jeg kan godt snakke med en person, men i bunn og grunn er det JEG som må bruke krefter og energi på å endre disse tingene ... Jeg vet ikke - jeg er så innstilt på å på en måte klare meg selv.» (Anna)

Etter ett år i behandling hadde de aller fleste sluttet med eller redusert selvskadingen betraktelig. De aller fleste ungdommene fremhevet også at behandlingen opplevdes nyttig. De verdsatte relasionen til terapeuten sin, men også muligheten til å snakke konkret om selvskadingsepisoder med en annen. Det var imidlertid ingen av dem som relaterte det å slutte å skade seg direkte til behandlingen. Ungdommene beskrev det som noe de fant ut selv. De fant sin egen vei ut av selvskadingen. Analysen av veien ut av selvskade viste en variasjon $\mathrm{i}$ hva de opplevde hielpsomt. Anna fremhevet betydningen av å bli forstått:

«Han er veldig flink til å finne ut de forskjellige utloserne da ... Han sier at "ja, men situasjonen her hores veldig ut som den situasjonen du beskrev i fjor sommer' - ... Det er sånn: Oj! I fjor sommer? ... Ja, du 
reagerte på veldig samme måtte, sa veldig det samme, og du var like sint og på en måte - Og jeg tenkte bare sånn: Oj! Hva skjedde da? Jo, akkurat felles greia - at jeg ble dumpa begge gangene, liksom. Så uten at jeg på en måte tenker over det så hielper han meg i å hjelpe meg selv, hvis du skjønner».

I tillegg merket hun at hun utsatte selvskadingen og snakket mer stottende til seg selv:

«Nå tenker jeg: OK, Anna, tenk deg om to ganger. Er dette her noe du faktisk BØR giøre, eller kommer du kanskje muligens å angre på dette her i morgen? Så det er sånn - ja, hvis jeg kanskje muligens kommer til å angre på det i morgen, så ikke giør det, rett og slett. Sånn stopp og tenk - Og det hadde jeg ikke for. For var det egentlig bare følelser og sånn, og nå er det på en måte: følelser - stopp - tenk - handling».

For Elsa handlet det om å begynne å snakke om det vanskelige:

«Det å snakke med noen ... det har vært veldig nyttig ... snakke om det og diskutere det og prøve å finne ut ... jeg har aldri snakket med noen om det før».

Hun fant ut at det å giøre noe annet slitsomt og krevende, som å trene kick boxing, var hjelpsomt når hun ville skade seg:

«Helt klart å trene. Kick boxing er veldig bra. Jeg måtte bare finne ut av det på egenhånd», sa hun.

For Sofie var det avgiørende å bli respektert og få omsorg:

«Det å være der, det var litt sånn - det var greit og koselig, egentlig ... Det var rart. Jeg er ikke typen som snakker åpent med folk ... men dette var annerledes ... Derfor var det ok. Det var ikke SÅ kjipt. Det var lettere».

Sofie klarte etter hvert å be mer direkte om hielp:

«Men det var en natt jeg ... bare våknet og bare fuck livet, liksom. Og så ble det skikkelig ille og sånn, og så ringte jeg legen og spurte hva jeg skulle giøre. Så dro jeg til legen. Jeg har en veldig bra lege da, for hun - hun skulle - hun var på vei hjem da jeg ringte, og så tok hun seg tid til meg».

Denne studien fremhever en heterogenitet i ungdommers opplevelse av selvskading og endring - ulike veier inn og ut av selvskading. Funnene fremhever også betydningen av å forstå selvskade i lys av utviklingspsykologiske temaer i ungdomstiden - som å utvikle autonomi, selvstendighet og identitet (Erikson, 1980; Thapar et al., 2015). Med selvskadingen kan en person endelig ha funnet noe som hjelper, om enn med en forstrukket selvstendighet. Med kroppen kan det vanskelige håndteres og uttrykkes. Hvorfor slutte da?

Selv om ungdommene ikke relaterte det å slutte å skade seg direkte til behandlingen kan selvfølgelig behandlingen ha hatt en effekt som pasientene selv ikke kunne artikulere eller giengi. Reduksjon av selvskade kan ha vært knyttet til utforskningen av det vanskelige i livet med en annen, eller det å snakke om alternative mestringsstrategier. Likevel kan muligheten til å oppdage egne ressurser være sentralt i deres subjektive opplevelse av endring. Behandlingstiltak kan legge til rette for endring. Det kan likevel for noen være avgiørende å forsøke å forstå, knytte kontakt og allianse omkring det de selv opplever er nyttig med selvskadingen - hvilken funksjon selvskadingen har i deres hverdag - før de kan bli opptatte av å ville slutte å skade seg.

\section{Selvskadingens funksjon og vekting av viktige intervensjonsfokus i behandling}

Kunnskap om selvskadingens funksion kan nyansere forståelsen av virksomme elementer ytterligere - og fremheve betydningen av tilpasning og vekting av intervensjonsfokus på tvers av behandlingsmodellene. I et historisk perspektiv har forståelsen av selvskading endret seg fra å uttrykke håndtering av ubalanserte motivasionelle drifter og traume (Freud, 1901; Favazza, 1987), utviklingsvansker i nære relasjoner (Pao, 1969), til å bli betraktet som lært atferd forsterket av indre og ytre belønning (Nock, 2014). I de senere årene er selvskade forstått som et uttrykk for dårlig affektreguleringsevne - et forsøk på å få vekk indre smerte, oppnå kontroll og lettelse (Klonsky, 2007). Et nyere perspektiv er å undersøke handlingen som uttrykk for genetisk sårbarhet og nevrobiologisk ubalanse som kan forårsake impulsivitet og endret smerteterskel (Miller et al., 2019). Flere kunnskapsoppsummeringer fremhever at det er mest evidens for at selvskading har en affektregulerende funksion, og støtter et atferdsperspektiv og nevrobiologiske modeller (Klonsky, 2007; Klonsky et al., 2014; Miller et al., 2019; Nock, 2014).

Det er noen felles betraktninger i forståelsen av selvskadings funksjon i behandlingsmodellene KBT, DBT og MBT, og som kan ha betydning for en effektiv behandlingsprosess. Sentralt i behandlingsmodellene er at selvskade forstås som en konsekvens av nevrobiologisk sårbarhet og mangel på adekvat følelsesmessig validering og omsorg fra tidlig alder. Som ungdom og voksen, antas at vanskelige situasjoner kan trigge selvdestruktiv atferd for å regulere følelser og å reetablere en stabil selvopplevelse (Bateman \& Fonagy, 2008; Linehan, 1993; 2015; Williams, 2014; Saunders \& Smith, 2016). Selv om de ulike behandlingsmodellene, som nevnt, har flere felles elementer, kan intervensionsfokusene fremheve mer eller mindre et direkte arbeide med underliggende funksjoner av selvskading. En individuell tilpasning kan være viktig for å møte pasienter med ulik patologi, ulike behov og ressurser, eller i ulike perioder av en behandlingsprosess. Noen pasienter kan være motivert for å få konkrete råd og høre hva de skal giøre for å regulere følelser på en annen måte enn å skade seg. Når selvskadingen er redusert kan noen bli mer 
motivert for å jobbe videre med relasjonelle vansker, ensomhet eller konflikter hiemme. For andre kan det å utforske hva selvskadingen uttrykker og har som funksion i ens indre verden eller i en ytre vanskelig relasjonell sammenheng være avgiørende for å føle seg forstått og tatt på alvor før de vil slutte å skade seg. Utfordringen er at dette kan ta tid og innebære en risiko. Fare for «drop out» kan bli stor om vi fremhever et fokus på atferdsendring for sent eller for fort.

Selv om behandlingsmodellene deler en vektlegging av at selvskadingen kan uttrykke utviklingsvansker og utfordringer i nære relasjoner, fremhever senere kunnskapsoppsummeringer på selvskadingens funksjon sjelden utviklingspsykologisk kunnskap, relasjonelle perspektiver og sosiokulturelle faktorer, eller funn fra kvalitative studier (Klonsky, 2007; Klonsky et al., 2014; Miller at al., 2019; Nock, 2014). Samtidig starter selvskading i ungdomstiden - i overgangen til voksenlivet. Den økte forekomsten - spesielt blant jenter - kan fordre at vi ser selvskade i lys av psykisk lidelse, men også utviklingspsykologiske og sosiokulturelle forhold. Et heterogent forståelsesperspektiv på selvskadingens funksjon kan antyde noen sentrale intervensjonsfokus som bør vektes mer eller mindre med ulike pasienter eller i ulike faser av en behandling av selvskading.

Som nevnt fremheves evidens for at selvskade har en affektreguleringsfunksjon. Når det gielder ungdom som skader seg, så viser nevrobiologisk kunnskap at endringer i kroppen og hiernen i ungdomstiden kjennetegnes av mer utviklede områder for følelsesaktivering enn prefrontale områder for abstraksjon, problemløsning og eksekutive funksioner (Casey et al., 2008; Mills \& Tamnes, 2018). Det er en såkalt mismatch som kan øke sensitivitet og læring, men giøre følelsene strevsomme og øke impulsivitet. Kunnskap om nevrobiologisk utvikling i ungdomstiden kan bidra til en forståelse for hvorfor overveldende følelsesmessige erfaringer håndteres med mer risikopreget atferd i ungdomstiden. Det å utforske, nyansere og teste strategier for affektregulering bør derfor være en sentral bestanddel i behandling av ungdom og voksne som skader seg på tvers av behandlingsmodeller - som å trene hardt, ta en dusi, løpe, høre musikk, se en film, bli engasjert i noe eller være sammen med noen. Vi husker at for Lisa handlet det om å finne ut at kick boxing var en bra måte å få ut frustrasjon og «stress» - hun gienfant kontroll og balanse. For andre er det noe annet som kan få tiden til å gå slik at de overveldende følelsene roes ned.

Hva som er så vanskelig at det må reguleres, og hva selvskadingen er knyttet til, kan være veldig forskjellig fra person til person. I en nylig metasyntese av kvalitative studier på ungdommers opplevelse av selvskade fremhever ungdommer at de oppnår lettelse (fra overveldende selvhat eller å kjenne seg levende) og kontroll av vanskelige følelser (som desperasjon, frustrasjon og nummenhet), men også at de forsøker å uttrykke ikke aksepterte følelser og dele det vanskelige med andre i et fellesskap (Stänicke et al., 2018). De vil få vekk frustrasjon og holde det vanskelige for seg selv. Ungdommers beskrivelser vitner om at de skader seg for å beskytte noen. Samtidig beskriver de en kamp for å representere følelsesmessige erfaringer og spesielt sinne. Selvskade kan således uttrykke en konflikt mellom ulike psykologiske utviklingsbehov i ungdomstiden - et behov for autonomi og å finne en egen måte å uttrykke det vanskelige, men samtidig et vedvarende behov for omsorg. Ved å skade seg kan kroppen brukes til å håndtere og beholde det vanskelige i en privat verden - for å hverken bry omsorgspersoner eller venner. Vi husker at Anna verdsatte det å bli forstått og finne en forståelse for sine vansker og sin historie. Hun verdsatte rommet for refleksjon og utforskning. Selvskade kan forstås som affektregulering, men kan også vektlegges som et tilløp til kommunikasion i en relasjonell kontekst. Behandling kan tilby en mulighet for å fokusere på å være i og å uttrykke det vanskelige uten å føle at du selv dør eller at andre kollapser. I møte med en terapeut kan det uutholdelige representeres og utforskes kanskje for første gang. Det kan gi okt selvforståelse og selvtoleranse, samt tilby en måte å være i det vanskelige - som å snakke eller skrive, høre, spille eller lage musikk selv, tegne eller male, eller gråte, rope og bevege seg for å uttrykke følelsesmessig vanskelige og overveldende opplevelser.

Mange som skader seg mangler tillit og søker ikke hjelp. I ungdomstiden, der sosiale grenser og roller kan utprøves og identitet skal dannes (Erikson, 1980), er det mange som søker «solitude». Blodet vitner om liv, men også om en indre verden. Blodet kan assosieres med pubertet og fruktbarhet, men også sårbarhet og dødelighet. Selvskadingen kan ha en funksjon i å representere det vanskelige og uutholdelige overfor en selv vel så mye som overfor andre i en relasjonell og sosiokulturell sammenheng. For Sofia uttrykte selvskadingen en opplevelse av å bli overlatt til seg selv i et overveldende kaos - det var ingen som passet på. Selvskading kunne være relatert til omsorgssvikt og eksistensiell sårbarhet, men også subkulturell utforskning av grenser, identitet og behovet for et fellesskap. Hun verdsatte å få respekt, omsorg og at hennes vansker ble anerkjent av en annen. I møte med terapeutens mer forutsigbare utforskning i terapi kan grunnleggende tillit etableres eller reetableres giennom relasjonell utproving («epistemic trust») (Fonagy et al., 2019). Dette kan gi grunnlag for mer utadrettet sosial utforskning og relasjonell læring istedenfor eksistensiell utforskning mot egen kropp.

\section{Konklusjon}

Flere strukturerte multimodale behandlinger viser effekt, men effekten av spesifikke ingredienser må relateres til kunnskap fra psykoterapiforskning på felles-, pasient- og terapeutfaktorer, samt felles elementer mellom behandlingsmodellene. Kortere intervensionstiltak og digitale løsninger er under 
utvikling og vil antagelig inngå i fremtidens helsetjeneste. Digitale terapiløsninger kan senke terskelen for å be om hjelp, men også for å muliggiøre strukturerte edukative og rådgivende intervensjoner.

Multimodale behandlingsmodeller er nyttige og viktige fordi fenomenet er vanskelig å jobbe med. Samtidig må alle terapeuter jevnt og trutt lytte, forstå, utrede, sortere egne følelser, helst jobbe i team, og individuelt tilpasse behandlingen for den gieldende pasient ut ifra aktuelle rammer. Gjerne giennom både kasusformulering og diagnostisk vurdering. Vi bør også utforske symptomets funksjon, og utarbeide en felles forståelse av vanskene i samarbeid med pasienten. Vi bør høre hva som er vanskelig før vi trekker opp informasjon, edukasjon og behandlingstilbud. Vi må vise at vi bryr oss og er nysgierrige. Ikke anta at vi vet hva det handler om.

Ulike forskningsmetoder kan fremheve ulike aspekter ved et fenomen og så også ved selvskading og behandling. Blir vi for selektive på aksepterte forskningsmetoder kan vi miste kompleksiteten av syne. Heterogenitet kan derfor være et gode i valg av forskningsmetoder, behandlingsmetoder og -modaliteter, men også i forståelse av selvskadingens funksjon. Selvskade som affektregulering kan fremheve intervensjoner i form av eksponering og nyansering av mestringsstrategier. Selvskading som representasion og tilløp til kommunikasjon kan fremheve betydningen av å få et rom til refleksjon, deling og utforskning av andre uttrykkskanaler. Selvskade som eksistensiell utforskning kan understreke betydningen av tillit og sosial kontakt. Heterogenitet i tiltak og intervensjonsfokus bør vektes i enhver behandlingssammenheng fordi pasientene er forskjellige. En selvskader er ikke en selvskader.

\section{REFERANSER}

American Psychiatric Association. (2013). Diagnostic and Statistical Manual of Mental Disorders, 5th ed. American Psychiatric Association: Washington, DC.

Anderson, T., Crowley, M. E. I., Himawan, L., Holmberg, I. K., \& Uhlin, B. D. (2015): Therapist facilitative interpersonal skills and training status: A randomized clinical trial on alliance and outcome, Psychotherapy Research, doi: $10.1080 / 10503307.2015 .1049671$

Bateman, A. \& Fonagy, P. (2008). 8-year follow-up of patients treated for borderline personality disorder: mentalization-based treatment versus treatment as usual. American Journal of Psychiatry, 165, 631-638. doi: 10.1176/ appi.aip.2007.07040636.

Bateman, A. W., Gunderson, I., \& Mulder, R. (2015). Treatment of personality disorder. Lancet, 385(9969), 735-43. doi: 10.1016/So140-6736(14)61394-5.

Beck, E., Bo, S., Gondan, M., Poulsen, S., Pedersen, L., Pedersen, I., \& Simonsen, E. (2016). Mentalization-based treatment in groups for adolescents with borderline personality disorder (BPD) or subthreshold BPD versus treatment as usual (M-GAB): study protocol for a randomized controlled trial. doi: 10.1186/s13063-016-1431-0

Berger, E., Hasking, P., \& Martin, G. (2014). Adolescents' perspectives of youth non-suicidal self-injury prevention. Youth \& Society, 49(1), 3-22. doi: 10.1177/0044118X13520561
Bo, S., Sharp, C., Beck, E., Pedersen, I., Gondan, M., \& Simonsen, E. (2017). First empirical evaluation of outcomes for mentalization-based group therapy for adolescents with BPD. Personality Disorder, 8(4), 396-401. doi: $10.1037 /$ peroooo210.

Brown, T. B., \& Kimball, T. (2013). Cutting to live: A phenomenology of selfharm. Journal of Marital and Family Therapy, 39, 195-208. doi: 10.1111/i.17520606.2011.00270.X

Carey, T. A., \& Stiles, W. B. (2015). Some problems with randomized controlled trials and some viable alternatives. Clinical Psychology \& Psychotherapy, 23(1), 87-95. doi: http://dx.doi.org/10.1002/cpp.1942

Casey, B. I., Iones, R. M., \& Hare, T. A. (2008). The adolescent brain. Annals of the New York Academy of Sciences, 1124, 111-126. doi: 10.1196/ annals.1440.010

Castonguay, L. C., Eubanks, C. F., Goldfried, M. R., Muran, I. C., \& Lutz, W. (2015). Research on psychotherapy integration: Building on the past, looking to the future. Psychotherapy Research, 25(3), 365-382. doi: $10.1080 / 10503307.2015 .1014010$

Crawford, M. I., Thana, L., Farquharson, L., Palmer, L., Hancock, E., Bassett, P., ... Parry, G. D. (2016). Patient experience of negative effects of psychological treatment: results of a national survey. British Journal of Psychiatry, 208(3), 260-265. doi: 10.1192/bip.bp.114.162628

Cristea, I. A., Gentili, C., Palomba, D., Barbui, C., \& Cuijpers, P. (2017). Efficacy of Psychotherapies for Borderline Personality Disorder: A Systematic Review and Meta-analysis. IAMA Psychiatry, 1, 74(4), 319-328. doi: 10.1001/iamapsychiatry.2016.4287.

Erikson, E. H. (1980). Identity: Youth and crisis. New York: Norton.

Favazza, A. R. (1987). Bodies under siege. Self-mutilation, nonsuicidal self-injury, and body modification in culture and psychiatry (3rd ed). Baltimore: The Tohns Hopkins University Press.

Folmo, E. I., Karterud, S., Kongerslev, M., Kvarstein, E. H., \& Stänicke, E. (2019). Battles of the comfort zone: modelling therapeutic strategy, alliance, and epistemic trust - a qualitative study of mentalization-based therapy for borderline personality disorder. Journal of Contemporary Psychotherapy, 49, 141-151. doi: 10.1007/s10879-018-09414-3

Fonagy, P., Luyten, P., Allison, E., \& Campbell, C. (2019). Mentalizing, Epistemic Trust and the Phenomenology of Psychotherapy. Psychopathology, 52(2), 94-103. doi: 10.1159/000501526.

Fortune, S., Sinclair, I., \& Hawton, K. (2008). Help-seeking before and after episodes of self-harm: A descriptive study in school pupils in England. BMC Public Health, 8, 369-382. doi: 10.1186/1471-2458-8-369

Freud, S. (1901). The psychopathology of everyday life. Standard edition of the complete psychological works of Sigmund Freud (Vol. 6), 1-239. Translated by I. Strachey. London: Vintage \& Hogarth Press

Goldfried, M. R. (2018). Obtaining Consensus in Psychotherapy: What Holds Us Back? American Psychologist, 74(4). doi: 10.1037/ampoooo365

Hammer, I., Ludvigsen, K., Heggdal., D., \& Fosse, R. (2017). Reduksjon av unngåelsesatferd og innleggelser grunnet villet egenskade etter Basal Eksponeringsterapi (BET). Suicidologi, 1. doi: 10.5617/suicidologi.4682

Hawton, K., Witt, K. G., Taylor Salisbury, T. L., Arensman, E., Gunnell, D., Hazell, P., Townsend, E., \& Heeringen, K. (2016). Psychosocial interventions for self-harm in adults. Cochrane Database of Systematic Reviews, 12(5), CDo12189. doi: 10.1002/14651858.CDo12189.

Hawton, K., Witt, K. G., Taylor Salisbury, T. L., Arensman, E., Gunnell, D., Townsend, E., ... Hazell, P. (2015). Interventions for self-harm in children and adolescents. Cochrane Database of Systematic Reviews, 12, CDo12013. doi: 10.1002/14651858.CD012013.

Hazell, P., Martin, G., Mcgill, K. M., Kay, T., Wood, A., \& Harrington, R. (2009). Group Therapy for Repeated Deliberate Self-Harm in Adolescents: Failure of Replication of a Randomized Trial. Journal of the American Academy of Child and Adolescent Psychiatry, 48(6), 662-70. doi: 10.1097/ CHI.obo1zez181aOacec 
Hetrick, S. E., Robinson, I., Spittal, M. I., \& Carter, G. (2016). Effective psychological and psychosocial approaches to reduce repetition of self-harm: a systematic review, meta-analysis and meta-regression. BMI Open 6(9), E011024. doi:10.1136/bmiopen-2016-011024

Holth, F., Walby, F., Røstbakken, T., Lunde, I., Ringen, P. A., Ramleth, R. K., ... Kvarstein, E. H. (2018). Extreme challenges: psychiatric inpatients with severe self-harming behavior in Norway: a national screening investigation. Nordic Journal of Psychiatry. doi: 10.1080/08039488.2018.1511751

Hutsebaut, I., Debbané, M., \& Sharp, C. (2020). Designing a range of mentalizing interventions for young people using a clinical staging approach to borderline pathology. Borderline personality disorder and emotion dysregulation, 7(6). doi:10.1186/s40479-020-0121-4

Huxley, E., Lewis, K. L., Coates, A. D., Borg, W. M., Miller, C. E., Townsend, M. L., \& Grenyer, B. F. S. (2019). Evaluation of a brief intervention within a stepped care whole of service model for personality disorder. BMC Psychiatry, 19, 341. doi: 10.1186/s12888-019-2308-Z

Iohnson, D. R., Ferguson, K., \& Copley, I. (2017). Residential staff responses to adolescents' self-harm: The helpful and unhelpful. Clinical Child Psychology and Psychiatry, 22, 443-454. doi: 10.1177/1359104516689378

Katsakou, C., Marougka, S., Barnicot, K., Savill, M., White, H., Lockwood, K. \& Priebe, S. (2012). Recovery in borderline personality disorder (BPD): A qualitative study of service users' perspectives. PLoS ONE, 7(5), 1. doi: 10.1371/journal.pone.0036517

Klonsky, E. D. (2007). The functions of deliberate self-iniury: A review of the evidence. Clinical Psychology Review, 27, 226-239. doi: 10.1016/i. cpr.2006.08.002

Klonsky, E. D., Victor, S. E., \& Saffer, B. V. (2014). Nonsuicidal self-injury: What we know, and what we need to know. The Canadian Journal of Psychiatry, 59(11), 565-568. doi: 10.1177/070674371405901101

Kongerslev, M. T., Chanen, A. M., \& Simonsen, E. (2015). Personality disorder in childhood and adolescence comes of age: a review of the current evidence and prospects for future research. Scandinavian Iournal of Child and Adolescent Psychiatry and Psychology, 3(1), 31-48. doi: 10.21307/sicapp 2015-004

Lindgren, B.-M., Wilstrand, C., Gilie, F. \& Olofsson, B. (2004). Struggling for hopefulness: A qualitative study of Swedish women who self-harm. Journal of Psychiatric and Mental Health Nursing, 11, 284-291. doi: 10.1111/i.1365 $2850.2004 .00712 . \mathrm{X}$

Lambert, M. I. (2013). The efficacy and effectiveness of psychotherapy. I M.J. Lambert (red.), Bergin \& Garfield's Handbook of Psychotherapy and Behavior Change (6th ed.). New York: Wiley.

Larsen, K. (2011). Bare gå og heng deg, din jævla dritt!". Motoverforing og suicidalitet. Suicidologi, 16(1), 18-24. doi: 10.5617/suiciologi.2070

Laurenssen, E. M., Westra, D., Kikkert, M. I., Noom, M. I., Eeren, H. V., van Broekhuyzen, A. I..... Dekker, I. I. (2014). Day hospital mentalization-based treatment (MBT-DH) versus treatment as usual in the treatment of severe borderline personality disorder: Protocol of a randomized controlled trial. BMC Psychiatry, 14, 149. doi: 10.1186/1471-244X-14-149.

Linehan, M. M. (1993). Cognitive-behavioral treatment of borderline personality disorder. New York: The Guildford Press.

Mehlum, L., Ramleth, R.-K., Tormoen, A. I., Haga, E., Diep, L. M., Stanley, B. H., ... Groholt, B. (2019). Long term effectiveness of dialectical behavior therapy versus enhanced usual care for adolescents with self-harming and suicidal behavior. Journal of Child Psychology and Psychiatry, doi: 10.1111/ ісрр.13077

Miller, A. B., Massing-Schaffer, M., Owens, S., \& Prinstein, M. I. (2019). Nonsuicidal self-iniury among youth. In TH Ollendick, S.W. White, \& B.A. White (Eds.), The Oxford Handbook of Clinical Child and Adolescent Psychology. Oxford: Oxford University Press. doi: 10.1093/ oxfordhb/9780190634841.013.34

Mills, K. L., \& Tamnes, C. K. (2018). Longitudinal Structural and Functional Brain Development in Childhood and Adolescence. PsyArXiv. doi:10.31234/ osf.io/87kft.
Muehlenkamp, I. I., Marrone, S., Gray, I. S., \& Brown, D. L. (20og). A college suicide prevention model for American Indian students. Professional Psychology: Research and Practice, 40(2), 134-140. doi: 10.1037/a0013253

Nissen-Lie, H. A. (2018). Effekten av psykodynamisk psykoterapi: Status i kunnskapsfeltet og ubesvarte sporsmål. Tidsskrift for Norsk Psykologforening, 55(6), 416-427.

National Institute for Health and Care Excellence (2019). Self-harm. Pathways. https://pathways.nice.org.uk/pathways/self-harm

Nock, M. K. (2014). The Oxford handbook of suicide and self-injury. New York: Oxford University Press.

Ougrin, D. \& Asarnow, I. R. (2018). The end of family therapy for self-harm, or a new beginning? Lancet Psychiatry. doi: 10.1016/ S2215-0366(18)30043-9

Ougrin, D., Tranah, T., Stahl, D., Moran, P., \& Asarnow, I. R. (2015). Therapeutic interventions for suicide attempts and self-harm in adoles cents: Systematic review and meta-analysis. Journal of the American Academy of Child and Adolescent Psychiatry, 54(2), 97-107. doi: 10.1016/i. iac.2014.10.009.

Pao, P.-N. (1969). The syndrome of delicate self-cutting. British Tournal of Medical Psychology, 42, 195-206. doi: 10.1111/j.2044-8341.1969.tbo2071.X

Ramvi, M. D. \& Huvestad, A. M. (2019). «Ta visst gör det ondt».

Psykoterapeuters folelsesmessige erfaringer i relasioner til ungdommer som skader seg selv. Hovedoppgave, Psykologisk Institutt, Universitetet i Oslo.

Rayner, G., Blackburn, I., Edward, K-L., Stephenson, I., \& Ousey, K. (2018) Emergency department nurse's attitudes towards patients who self-harm: A meta-analysis. Mental Health Nursing, 28(1), 40-53. doi: 10.1111/inm.12550

Robstad, S. E. (2018). «De lever med meg». Terapeuters erfaringer fra arbeide med ungdommer som skader seg selv. Hovedoppgave, Psykologisk institutt, Universitetet i Oslo. http://urn.nb.no/URN:NBN:no-69477

Rosenzweig, S. (1936). Some implicit common factors in diverse methods of psychotherapy. American Journal of Orthopsychiatry, 6(3), 412-415.

Rossouw, T. I., \& Fonagy, P. (2012). Mentalization-based treatment for selfharm in adolescents: A randomized controlled trial. Journal of the American Academy of Child Adolescent Psychiatry, 51, 1304-1313. doi: 10.1016/i. jaac.2012.09.018

Roth, A., \& Fonagy, P. (2005). What works for whom? A critical review of psychotherapy research (2nd ed.). New York: Guilford Press.

Rønnestad, M. H. (2008). Evidensbasert praksis i psykologi. Tidsskrift for Norsk psykologforening, 45(4), 444-454

Saunders, K. E.., Hawton, K., Fortune, S., \& Farrell, S. (2012). Attitudes and knowledge of clinical staff regarding people who self-harm: A systematic review. Journal of Affective Disorders, 139, 205-216. doi: 10.1016/i. jad.2011.08.024

Saunders, K. E., \& Smith, K. A. (2016). Interventions to prevent self-harm: What does the evidence say? Evidence-Based Mental Health, 19, 69-72. doi: 10.1136/eb-2016-102420

Saxon, D. \& Barkham, M. (2012). Patterns of Therapist Variability: Therapist Effects and the Contribution of Patient Severity and Risk. Journal of Consulting and Clinical Psychology, 8o(4), 535-46. doi: 10.1037/a0028898

Sosial- og helsedirektoratet. (2008). IS-1511: Nasionale retningslinier for forebygging av selvmord i psykisk helsevern. IS-1511. ISBN 978-82-8081-o98-4

Stangeland, T. (2016). I skyggen av selvmordsrisiko. Scandinavian Psychologist, 3, e3. doi: 10.15714/scandpsychol.3.e3

Storebø, O. I., Stoffers-Winterling, I. M., Völlm, B. A., Kongerslev, M. T., Mattivi, I. T., Jorgensen, M. S., Faltinsen, E., Todorovac, A., Sales, C. P., Callesen, H. E., Lieb, K., \& Simonsen, E. (2020). Psychological therapies for people with borderline personality disorder. Cochrane Database of Systematic Reviews, 5. Art. No.: CDo12955. doi: 10.1002/14651858.CDo12955. pub2. 
Stänicke, L. I., Haavind, H., \& Gullestad, S. E. (2018). How Do Young People Understand Their Own Self-harm? A Meta-synthesis of Adolescents Subiective Experience of Self-harm. Adolescent Research Review. doi:10.1007/s40894-018-0080-9

Stänicke, L. I., Haavind, H., Rø, F. G., \& Gullestad, S. E. (2019). Discovering one's own way: Adolescent girls' different pathways into and out of selfharm. Journal of Adolescent Research, 1-30. doi:10.1177/0743558419883360

Swannell, S. V., Martin, G. E., Page, A., Hasking, P., \& St. John, N. I. (2014). Prevalence of nonsuicidal self-injury in noncinical samples: Systematic review, meta-analysis and meta-regression. Suicide and Life-Threatening Behavior, 44, 273-303. doi: 10.1111/sltb.1207

Taylor, T. L., Hawton, K., Fortuna, S., \& Kapur, N. (2009). Attitudes towards clinical services among people who self-harm: Systematic review. British Tournal of Psychiatry, 194, 104-110. doi: 10.1192/bip.bp.107.046425

Tebbett-Mock, A. A., Saito, E., McGee, M., Woloszyn, P., \& Venuti, M. (2019). Efficacy of Dialectical Behavior Therapy Versus Treatment as Usual for Acute-Care Inpatient Adolescents. I Am Acad Child Adolesc Psychiatry. 59(1),149-156. doi: 10.1016/i.jaac.2019.01.020.

Turner, B. I., Austin, S. B., \& Chapman, A. L. (2014). Treating nonsuicidal self-injury: A systematic review of psychological and pharmacological interventions. Canadian Journal of Psychiatry, 59(11), 576-585. doi: 10.1177/070674371405901103

Tormoen, A. I., Myhre, M., Walby, F. A., Groholt, B., \& Rossow, I. (2020). Change in prevalence of self-harm from 2002 to 2018 among Norwegian adolescents. European Journal of Public Health, ckaao42, doi: 10.1093/ eurpub/ckaao42

Wadman, R., Vostanis, P., Sayal., K., Majumder, P., Harroe, C., Clarke, D., ... Townsend, E. (2018). An interpretative phenomenological analysis of young people's self-harm in the context of interpersonal stressors and supports: Parents, peers, and clinical services. Social Science and Medicine, 212, 120128. doi: 10.1016/i.socscimed.2018.07.021

Wampold, B., \& Imel, Z. E. (2015). The great psychotherapy debate: The evidence for what makes psychotherapwork (2nd ed.). New York: Routledge.

Weinberg, I., Ronningstam, E., Goldblatt, M. I., Schechter, M., \& Maltsberger, I. T. (2011). Common factors in empirically supported treatments of borderline personality disorder. Current Psychiatry Rep, 13, 60-68 doi:10.1007/ s11920-010-0167-X

Williams, M. (2014). Cry of pain. Understanding suicide and the suicidal mind. London: Little, Brown Book Group.

Willig, C. (2013). Introducing qualitative research in psychology. New York: Open University Press.

Witt, K., Spittal, M. I., Carter, G., Pirkis, I., Hetrick, S., Currier, D., Robinson, I., \& Milner, A. (2017). Effectiveness of online and mobile telephone applications ('apps') for the self-management of suicidal ideation and self-harm: a systematic review and meta-analysis. BMC Psychiatry, 17, 297. doi: 10.1186/ S12888-017-1458-0

Østlie, K., Stänicke, E., \& Haavind, H. (2018). A listening perspective in psychotherapy with suicidal patients: Establishing convergence in therapists and patients' private theories on suicidality and cure. Psychotherapy Research, 28(1), 150-163. doi: 10.1080/10503307.2016.1174347

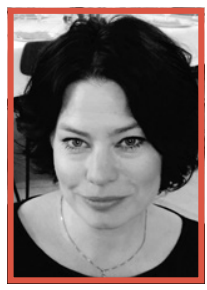

LINE STÄNICKE er førsteamanuensis ved Psykologisk institutt/Universitetet i Oslo og er tilknyttet Nic Waals Institutt/ Lovisenberg sykehus. 